\title{
Students' Creative Thinking With 4'R Applications in Procedure Text Project Based Learning
}

\author{
Kusmiati Dariman \\ Sabilillah Islamic Junior High School Malang \\ Upper Piranha Canal No. 135 Malang, East Java, Indonesia \\ kusmiatidariman77@gmail.com \\ ${ }^{*}$ Corresponding Author
}

How to Cite: Dariman, K. (2018). Students' Creative Thinking With 4'R Applications in Procedure Text Project Based Learning. International Journal for Educational and Vocational Studies, 1(1), 15-20. DOI: https://doi.org/10.29103/ijevs.v1i1.1375

\section{ARTICLE HISTORY}

Received: 5 February 2019

Revised: 20 March 2019

Accepted: 11 April 2019

\section{KEYWORDS}

Creative Thinking

4'R (Reading, writing, Reasoning, and

arithmetic)

Prosedure Text

Project Based Learning

\section{ABSTRACT}

The application of 4'R (Reading, Reciting, Reasoning, and aRithmetic) is very important to be applied in an integrated way in learning. The purpose of this study was to describe students 'creative thinking with the application of 4' R (Reading, Reciting, Reasoning, and aRithmetic) in project-based text learning. This study uses Classroom Action Research method. The research subjects were students of grade VIIA Sabilillah Islamic Junior High School Malang. The results showed that students' creative thinking skills were still very low, namely $61.29 \%$. Based on the facts found the learning process has not taken place optimally. Finally, after applying 4 'R (Reading, Reciting, Reasoning, and aRithmetic) in project-based learning. Students' creative thinking skills on average experienced an increase after improvements were made with the implementation of the 4 ' $R$ and project-based learning. This can be shown in the increasing percentage of skills reaching an average of $77,46 \%$ in the first cycle and increasing in the second cycle reaching a percentage of $96.77 \%$.

This is an open access article under the CC-BY-SA license.

\section{INTRODUCTION}

Based on the 2013 curriculum according to Harsiati (2016) that text-based Indonesian language learning gives freedom to a teacher to apply several principles including: (1) language should be seen as text, not merely a collection of linguistic words or rules, (2) the use of language is the process of selecting linguistic forms to express meaning, (3) language is functional, that is the use of language that can never be released from the context because in the form of language it is reflected by the ideas, attitudes, values, and ideology, and (4) language is a means of forming human thinking abilities.

In connection with these principles, it needs to be realized that in each text there are separate structures that are different from each other. Meanwhile, the text structure reflected the structure of thinking. Thus, the more types of text mastered by students, the more the structure of thinking that can be used in later social and academic life. Only in that way, students then construct their knowledge through the ability to observe, question, associate, analyze, and present the results of analysis adequately.

Besides that, learning is needed to develop $21^{\text {st }}$ century skills, which include $4 \mathrm{C}^{\text {'s }}$ skills (critical thinking, creative and innovation, collaboration, and communication), character strengthening, and literacy. According to Beers (2011) emphasizes that good learning is learning that can facilitate students in achieving $21^{\text {st }}$ century skills with the following criteria: (1) providing more varied opportunities and learning activities; (2) utilizing technology to achieve learning goals; (3) project-based learning or problems; (4) connecting between curricula (cross-curricular connections); (5) focusing on investigations/inquiry and investigations conducted by students; (6) collaborative learning environment; (7) high-level visualization and using visual media to improve understanding; (8) using formative assessment including self-assessment. For therefor, an effort is needed to continue to innovate and make adjustments in learning according to the demands of the $21^{\text {st }}$ century. One way to innovate is developing strategies in learning to develop $21^{\text {st }}$ century skills, one of which is creative thinking skills.

Meanwhile, $21^{\text {st }}$ century learning calls for new learning models that bring new forms of learning that are needed in overcoming complex global challenges. Students are able to identify the things that are important and need to be done on their future challenges. Students must develop critical 
thinking skills, think creatively, collaborate, and communicate well and be able to show good and independent characters. Every individual must be involved in learning that is meaningful, has truth value and relevance, to develop high-level thinking skills that they really need in the future (Barron and Darling-Hammond, 2008).

The teacher must be able to understand that each student learns in different ways, so that the teacher is also challenged to find ways to help all students learn effectively. One of the lessons that is able to develop 21st century skills is project-based learning. A number of studies have shown that learning with PjBL turns out to be capable of real experience. The product in question is the result of the project in the form of design, scheme, paper, artwork, technological/craft work, and others. This approach is better able to develop students' ability to work independently or in groups to produce real products.

In addition, the application of 4'R (Reading, Reciting, Reasoning, and aRithmetic) in a text learning procedure proved to be able to integrate all four language skills as well as numeracy in learning. Remembering the text of the procedure requires an accurate measure of size so students must learn about aRithmetic before doing the project-based learning.

The background of this study is that in general, students in Sabilillah Islamic Junior High School in Malang in learning Indonesian in the competence to demonstrate procedure text are still largely unable to meet the assessment criteria that show creative thinking skills. Learning is considered less optimal and unsatisfactory for students. Thus, researchers will try to implement learning with the right strategy.

The application of 4 ' $\mathrm{R}$ is an effective strategy to stimulate students interested in learning to demonstrate procedure text that are carried out at home as a project. By using strategy, it allows students to learn more actively and effectively. Besides, it can also foster a sense of responsibility, respect, caring, and being able to work with friends.

In this case, the application of 4'R (Reading, Reciting, Reasoning, and aRithmetic) as an alternative choice in filling out the competency weaknesses, being able to develop students' creative thinking skills in presenting procedure texts through video impressions. With this strategy students are expected to be able to think creatively in demonstrate procedure text and have the willingness to actively participate in learning.

There are some advantages of 4'R implementation, so this study aims to describe students 'creative thinking skills by implementing 4' $\mathrm{R}$ in project-based text learning procedure.

\section{METHODS}

The study was conducted at Sabilillah Islamic Junior High School in Malang. The research subjects were 31 students of grade VIIA graders. The study was conducted starting on
October 4, 2018 up to January 24, 2019. The duration of the study was around 4 months.

The procedure of research is classroom action research which carried out in a cyclical manner, namely planning (which begins with a preliminary study), implementation of actions, observations and reflections. When the implementation of a new problem arises, the researcher can repeat planning, action, observation, and reflection so as to form an increasingly better cycle (Arikunto, 2015).

Data obtained from observation sheets, student performance sheets, and student products in the form of short stories. To observe the development of creative thinking skills, the observation sheet was used. Observations are made during the cycle. The results of student performance are obtained based on the assessment rubric demonstration procedure text.

Data collection is done by observation, documentation, and product of students.

Data analysis was done by filling in the observation sheet and giving percentages to the level of creative thinking skills and student literacy in learning for qualitative data. Quantitative data is obtained through performance rubrics based on the assessment of writing procedure texts.

\section{RESULTS AND DISCUSSION}

This research was conducted in two cycles. The results in this study are based on classroom action research conducted per cycle.

\subsection{Pre-cycle}

Based on the preliminary study, it was found that the students' problems in demonstrate procedure text were as follows: (1) the fluency in presenting the texts of each procedure was very lacking, (2). giving less choice alternatives in presenting procedure texts, (3) the vocabulary chosen in writing procedure texts is not correct, (4) the size used is not accurate, (5) less able to describe in detail the ideas in presenting the text of the procedure, and (6) steps to explain the process from the beginning to the end of the creation of a product/how to do it less complete.

The lack of optimal learning shows the results of students' creative thinking skills are still far below the KBM (Minimum Learning Completeness), which is 75.

From the data above, it is known that students 'creative thinking skills before applying 4' R (Reading, Reciting, Reasoning, and aRithmetic) have not shown maximum results. Whereas according to the success criteria of the action states that a class is said to have $85 \%$ creative thinking skills, including fluency, flexible thinking, flexibility, originality thinking, elaboration, and evaluation.

The ifluency in thinking skills shown by students in learning activities presenting procedure texts only reached $77.41 \%$, flexibility thinking skills reached a percentage of $75.00 \%$, originality reached $65.32 \%$, elaboration reached 
the percentage of $77.41 \%$, and the skill of evaluating reaches $70.16 \%$.

Student accomplishment data classically there are 19 students and 12 students have not been accomplished from the total of 31 students. Learning outcomes presenting procedure texts to students achieving success indicators are in accordance with KBM 75 so that there are 12 students who must get special treatment for remedial.

\subsection{Cycle I}

The results of the observation on the first cycle showed a fairly rapid increase in students' creative thinking skills during learning. For fluency that is shown by students in learning activities presents procedure texts reaching a percentage of $79.83 \%$, percentage in thinking flexible (flexibility) reaches $87.90 \%$, original thinking (originality) reaches $74.19 \%$, elaboration reaching $84.67 \%$, and evaluating to reach $76.61 \%$.

Table 1. Outcome Results Skills of creative thinking in pre-cycle and cycle I

\begin{tabular}{lcccc}
\hline Creative Thinking Skills & \multicolumn{2}{c}{ Pre-Cycle } & Cycle I \\
\hline & Total of Students & Percentage of Completeness & Total of Students & Percentage of Completeness \\
Completed & 19 & $61,29 \%$ & 24 & $77,42 \%$ \\
Not Completed & 12 & $38,70 \%$ & 7 & $22,58 \%$ \\
Total & 31 & $100 \%$ & 31 & $100 \%$ \\
\hline
\end{tabular}

Classically learning presents the text of this procedure has not been accomplished calcified. However, the percentage of completeness has reached an increase of 61 , $29 \%$ to $77.42 \%$ with a percentage increase of $16.14 \%$. While students who did not complete dropped from $38.70 \%$ to $22.58 \%$.

\subsection{Cycle II}

The observation of the second cycle shows that students' creative thinking skills have increased quite rapidly. For fluency skills shown by students in procedural text learning activities reached a percentage of $93.54 \%$, the percentage of flexible thinking (flexibility) reached $94.35 \%$, originality in expressing ideas presented the procedure text reached $80.64 \%$, the percentage of elaboration skills reached $84.67 \%$ and the students' evaluation skills reached $81.45 \%$.

Table 2. Outcome Results Skills of Creative Thinking in Cycle I dan Cycle II

\begin{tabular}{lcccc}
\hline Creative Thinking Skills & \multicolumn{2}{c}{ Cycle I } & Cycle II \\
\hline & Total of Students & Percentage of Completeness & Total of Students & Percentage of Completeness \\
Completed & 24 & 77,42 & 30 & 96,77 \\
Not Completed & 7 & 22,58 & 1 & 3,23 \\
Total & 31 & 100 & 31 & 100 \\
\hline
\end{tabular}

Classically this fable storytelling skill is not yet complete. The percentage of completeness has reached an increase from $77.42 \%$ to $96.77 \%$ with a percentage increase of $19.35 \%$.

\subsection{The Improvement of Creative Thinking Skills by Applying 4R in Demonstrating Procedure Text Project Based Learning}

Improving creative thinking skills in project-based learning in demonstrating procedure text by applying the 4'R strategy (Reading, Reading, Reasoning, and aRithmetic). This can be seen based on quantitative values in the form of observation sheets based on assessment rubrics whose indicators are fluency with the criteria students are able mention/write down ideas in demonstrating procedure text with alternative logical reasons, flexible thinking with the criteria that students are able to write several alternative answers that are very logical and relevant to the problem given related to the text of the procedure from a variety of different perspectives, original thinking (originality) with the criteria that students are able to mention/write down some unique ideas that are logically interesting, relatively new and relevant to the problem given in presenting procedure text, elaboration with the criteria that students are able to describe some logical details on existing ideas. So that the formulation of ideas in presenting procedure texts becomes more easily applied and clear in the work, and evaluates (evaluates) by criteria students are able to combine some information about procedure text as ideas, modify, and explain formulas with logical and coherent analogies in the work.

The improvement of creative thinking skills shown in pre-cycle, cycle I and cycle II is very significant. The increase was obtained from the number of students completeness and the incompleteness of students in learning to write these fantasy stories from each cycle. For more details, the increase can be seen from the value of student completeness in the following table. 
Table 3. Outcome Results Skills of Creative Thinking

\begin{tabular}{lccc}
\hline \multirow{2}{*}{ Creative Thinking Skills } & \multicolumn{3}{c}{ Table 3. Outcome Results Skills of Creative Thinking } \\
\cline { 2 - 4 } & Pre-Cycle & Cycle I & Cycle II \\
\hline Completed & 61,29 & 77,42 & 96,77 \\
Not Completed & 38,70 & 22,58 & 3,23 \\
Total & 100 & 100 & 100 \\
\hline
\end{tabular}

To be clearer, the improvement of creative thinking skills in project-based learning demonstrate procedure text by applying 4'R VIIA students in Sabilillah Islamic Junior High School in Malang including fluency, flexibility, originality, thinking in detail (elaboration), and the ability to evaluate (evaluation) can be seen in Figure 1 below.

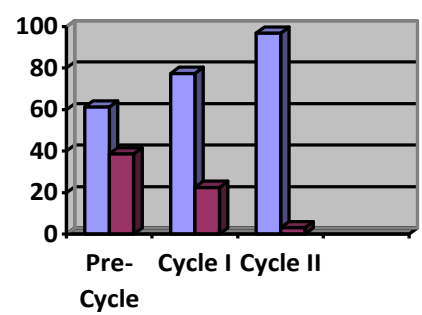

\begin{tabular}{|l|}
$\square$ Completed \\
$\square$ Not Completed
\end{tabular}

Figure 1. Increase Creative Thinking Skills

Based on Figure 1 above, it can be seen clearly that the percentage of completeness of VIIA students in pre-cycle reached $61.29 \%$, while in the first cycle there was an increase of $77.42 \%$, and in the second cycle it reached $96.77 \%$ and an incompleteness occurred in the cycle. pre-cycle reaches $38.70 \%$, then in the first cycle the percentage reaches $22.58 \%$, and in the second cycle the percentage reaches $3.23 \%$ and has been remedial in 1 student to achieve completeness individually. Based on the increase in the percentage of completeness the students proved that the application of 4'R (Reading, Reciting, Reasoning, and aRithmetic) succeeded in increasing creative thinking skills in the presentation of project-based text procedure in class VIIA Sabilillah Islamic Junior High School Malang.
Based on these improvements, creative thinking skills turned out to provide various possible answers based on the information provided with an emphasis on diversity of numbers and suitability (Munandar, 2012). Creative thinking is a way of thinking that produces something new in presenting the concept of applying 4 ' $R$ in learning to demonstrate prosedures text based on project based learning.

In the first cycle, it was found that students' creative thinking skills improved. It is based on indicators that occur during learning, which shows students are better able to smooth thinking, flexibility of thought, authenticity of mind, elaboration, and ability to judge. More capable of thinking fluently is shown by behavior that is able to mention/write ideas in demonstrate procedure text with logical reasons, flexibility is shown in students' ability to write several alternative answers that are very logical and relevant to the problem given related to procedure text from various different perspectives, originality is shown by the behavior of students able to mention/write down some unique ideas that are logically interesting, relatively new and relevant to the problems given in demonstrate the procedure text, elaboration indicated by the behavior of students capable describes some logical details on existing ideas so that the formulation of ideas in demonstrate procedure text becomes more easily applied and clear in the work, and evaluation skills are indicated by the ability to combine some information about procedure text as ideas, modify, and explain the formula by logical and coherent analogy in the work. In cycle II, creative thinking skills include fluency in thinking, flexibility of thinking, authenticity of mind, detailing, and judging which shows an increasing percentage. The following table increases.

Table 4. Creative Thinking Skills in Learning

\begin{tabular}{lll}
\hline \multirow{2}{*}{ Aspect of Creative Thinking } & \multicolumn{2}{c}{ Percentage (\%) } \\
\cline { 2 - 3 } & Pre-Cycle & Cycle I \\
\hline Fluency & 77,41 & 79,83 \\
Flexibility & 75,00 & 87,90 \\
Originality & 65,32 & 74,19 \\
Elaboration & 77,41 & 84,67 \\
Evaluation & 70,16 & 84,35 \\
\hline
\end{tabular}




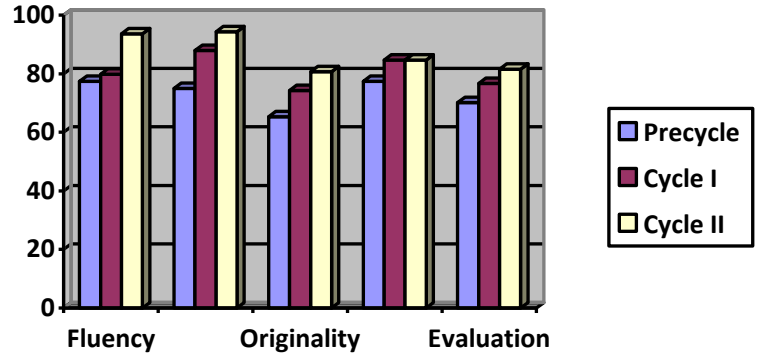

Figure 2. Creative Thinking Skills in Learning

Based on the graph, students' creative thinking skills during learning took place increase from each cycle with an average of $61.29 \%$ in the cycle to an increase of $77.42 \%$ in the first cycle and becoming $96.77 \%$ in the second cycle, both in terms of fluency ), flexibility of thinking (originality), elaboration, and evaluation according to the assessment criteria.

This is in line with the statement that creative thinking skills are mental activities related to sensitivity to a problem, consider new information and ideas that are not usually with an open mind, and can make relationships in solving a problem. According to Munandar (2012), argues that the characteristics of creative thinking skills related to cognition can be seen from fluency, flexibility, originality, elaboration, and evaluation.

Munandar (2012) further said that schools have a role in developing student creativity, especially in learning. For this reason, the activity of presenting fantasy stories requires the creativity and innovation of educators in order to develop students' creative thinking skills optimally through the above steps.

The application of 4'R (Reading, Reciting, Reasoning, and aRithmetic) turns out to have an enjoyable learning effect for students because students are directly involved in managing information about the procedure text that is obtained through reading activities, then rewriting ideas in writing procedure text using their language themselves, then think critically in reviewing procedure text that is read and written, and the last is to examine the size/dose used in procedure text that has been written logically through testing at the aRithmetic stage. This is in line with the opinion of Slavin (2015) which states that the learning model is a reference to the learning approach used in accordance with the objectives, syntax, environment, and management system that leads to the steps taken in the learning, namely applying 4 ' $\mathrm{R}$ that is, sequential stages starting from Reading, Reciting, Reasoning, and aRithmetic.

In addition, learning presents a packed procedure text in project based learning that allows students to develop 21 st century skills that are the focus of this research is creative thinking skills. This shows that project based learning is very suitable for use in learning to present procedural text so that students are able to develop creative thinking skills in presenting the text of the procedure. In project based learning, students work more individually and in groups to construct knowledge, then students become collaborators in the process of developing understanding. Project based learning provides an understanding of actual knowledge. Students will do their own exploration, assessment, interperetation and synthesis in understanding information.

According to Trisdiono (2013), it argues that project based learning, is not teacher oriented but student oriented which directly teaches teachers, accompanies, facilitates, and understands the minds of students. The nature of project work is collaborative, so the development of these skills takes place among students, in the process and product outcomes of projects carried out in groups, by prioritizing individual strengths and strengthening teamwork as a whole for maximum learning outcomes.

In line with this, according to Sunardi (2017) states that project based learning (PjBL) is learning that uses projects /activities as a learning process to achieve competency in attitudes, knowledge and skills. The emphasis of learning lies in the activities of students to produce products by applying the skills of researching, analyzing, making, to presenting learning products based on real experience. Skills are emphasized by implementing 4'R (Reading, wRiting, Reasoning, and aRithmetic). The product in question is the result of the project in the form of design, scheme, paper, artwork, technological/craft work, and others. This approach allows students to work independently or in groups to produce tangible products, the products produced in the form of videos demonstration procedure text.

The application of 4 ' $R$ is also in accordance with the stages of Reading, Writings, Reasoning, and aRithmetic in a coherent manner in learning in Indonesian language that should be well integrated in each stage to be full to achieve maximum learning goals. In line with the opinion of Mahsun (2014), he stated that the ultimate goal of text-based Indonesian language learning is to make learning understand and be able to use text in accordance with the social objectives of the texts studied.

The application of 4'R also agrees with Asrofah (2018) which states that learning Indonesian language is expected to help students know themselves, their culture, and the culture of others, express ideas and feelings, participate in communities that use the language and find and use analytical skills and imaginative in him. Indonesian language learning is directed at improving students' ability to communicate in Indonesian language properly and correctly, both verbally and in writing, as well as fostering an appreciation of literary work. Departing from this, it is very necessary for students to be equipped with life skills through the $21^{\text {st }}$ century learning process, one of which is creative thinking skills. Thus the expected goals so that children have language skills can be achieved optimally. 


\section{CONCLUSION}

Based on the results of the study as described and discussed at the front, it can be concluded that in general the application of 4 ' $\mathrm{R}$ can improve creative thinking skills in project-based textual learning procedure for students in Malang Sabilillah Islamic Junior High School 2018/2019. This can be shown in the percentage of VIIA class creative thinking skills achieving completeness $77.42 \%$ in cycle I and completeness to $96.77 \%$ in cycle II. This shows that the application of 4 ' $\mathrm{R}$ in learning presents a project-based procedure text can improve students' creative thinking skills including aspects of fluency, flexibility, originality, elaboration, and evaluation.

\section{REFERENCES}

Arikunto, Suharsimi, Suhardjono, Supardi. (2015). Penelitian Tindakan Kelas. Jakarta: Bumi Aksara.

Asrofah. (2018). Pengembangan Pembelajaran Bahasa Indonesia Melalui Model Kooperatif Berbasis Life Skill. Journal.upgris.ac.id downloaded on December 21, 2018 at 9.35

Barron, B., \& Darling-Hammond, L. (2008). Powerful learning: Studies show deep understanding derives from collaborative methods. Edutopia.(October 2008). DOl= http://www. edutopia. org/inquiry-project-learning-research.

Beers, S. (2011). 21st century skills: Preparing students for their future. accesse from http://www. yinghuaacademy. org/wpcontent/uploads/2014/10/21st_century_skills. pdf.

Mahsun. (2014). Teks dalam pembelajaran bahasa Indonesia kurikulum 2013. PT. Raja Grafindo Persada.

Munandar, Utami. (2012). Mengembangkan Bakat dan Kreativitas Anak Sekolah.Jakarta: PT. Gramedia Widiasarana Indonesia.

Sunardi, Sujadi, Imam.(2017). Modul PLPG: Desain Pembelajaran. Kemedikbud: Dirjen GTK

Slavin, Robert E. (2015). Cooperatif Learning (Penerjemah Narulito Yusron). Bandung: Nusa Media.

Titik Harsiati.(2016). Buku Pegangan Guru Bahasa Indonesia Kurikulum 2013. Jakarta: Kemendikbud.

Trisdiono, Harli. (2013). Strategi Pembelajaran Abad 21. Yogyakarta: Lembaga Penjaminan Mutu Pendidikan Prov. D.I. Yogyakarta. melalui http//lpmp.jogya.org// downloaded on September 19, 2018 at 12.47 WIB. 